\title{
RELATIONSHIP BETWEEN TOTAL CHLOROPHYLL AND PHYTOPLANKTON INDIVIDUALS OF ROSETTA BRANCH OF RIVER NILE, EGYPT
}

\author{
A.M. Shaaba, H.A. Mansour and A.A.S. Saber ${ }^{\mathrm{a}, *}$ \\ ${ }^{a}$ Botany Department, Faculty of Science \\ Ain Shams University, Abbasia, Cairo, Egypt \\ *E-mail: abdullah_elattar@sci.asu.edu.eg
}

\begin{abstract}
Total chlorophyll concentrations of the phytoplanktonic samples of Rosetta branch of the River Nile at the stations before Edfina barrage (from station I to V) and after Edfina barrage (stations VI and VII) were studied during two successive years from August 2006 to April 2008. At all stations, the total chlorophyll contents of the identified algae and the maximum quantitative algal individuals were found maximum during summer 2007. Peak periods of total chlorophyll coincided with peak periods of the stations that recorded high algal biomass. Phytoplankton in Rosetta branch of the river Nile at the most studied stations (I, II, IV, V and VI) had chloro-character particularly in summer 2007. A positive correlation was observed between the fluctuations of total chlorophyll contents of the phytoplankton and those of total number of individuals at all investigated stations of Rosetta branch.
\end{abstract}

Key words: Microalgae biomass, algal chlorophylls, phytoplankton, Rosetta branch of river Nile.

\section{INTRODUCTION}

Biomass of micro-algae is a good source of nutrients and biologically active ingredients. Accordingly, estimation of algal biomass is very crucial. Chlorophyll concentration was widely used as a common predictor's technique for monitoring the reliability picture of dissolved nutrients and algal biomass in aquatic habitats (Fogg 1975, Tolstoy 1979, Desortová 1981, Vörös and Padisák 1991 and Kalchev et al. 1996 and Halil et al. 2008). Chlorophyll $a$ is the main photosynthetic pigment in all oxygen-evolving photosynthetic algae while other algal pigments have limited distribution and considered as accessory or secondary pigments (Akpan 1994). It constitutes approximately $1-2 \%$ of the dry weight of phytoplanktonic algae, its assessment is relatively easy, cheap and rapid to quantify in comparison to the analysis of a full suite of dissolved nutrients (Hakanson 1994, Passavante and Feitosa 2004, Brando et al. 2006, Shehata et al. 2008, Sobhy 2008, Todd et al. 2008 and Santos et al. 2010). In this paper, we analyze the relationship between total chlorophyll contents of the phytoplankton and their total number of individuals in Rosetta branch of river Nile. 


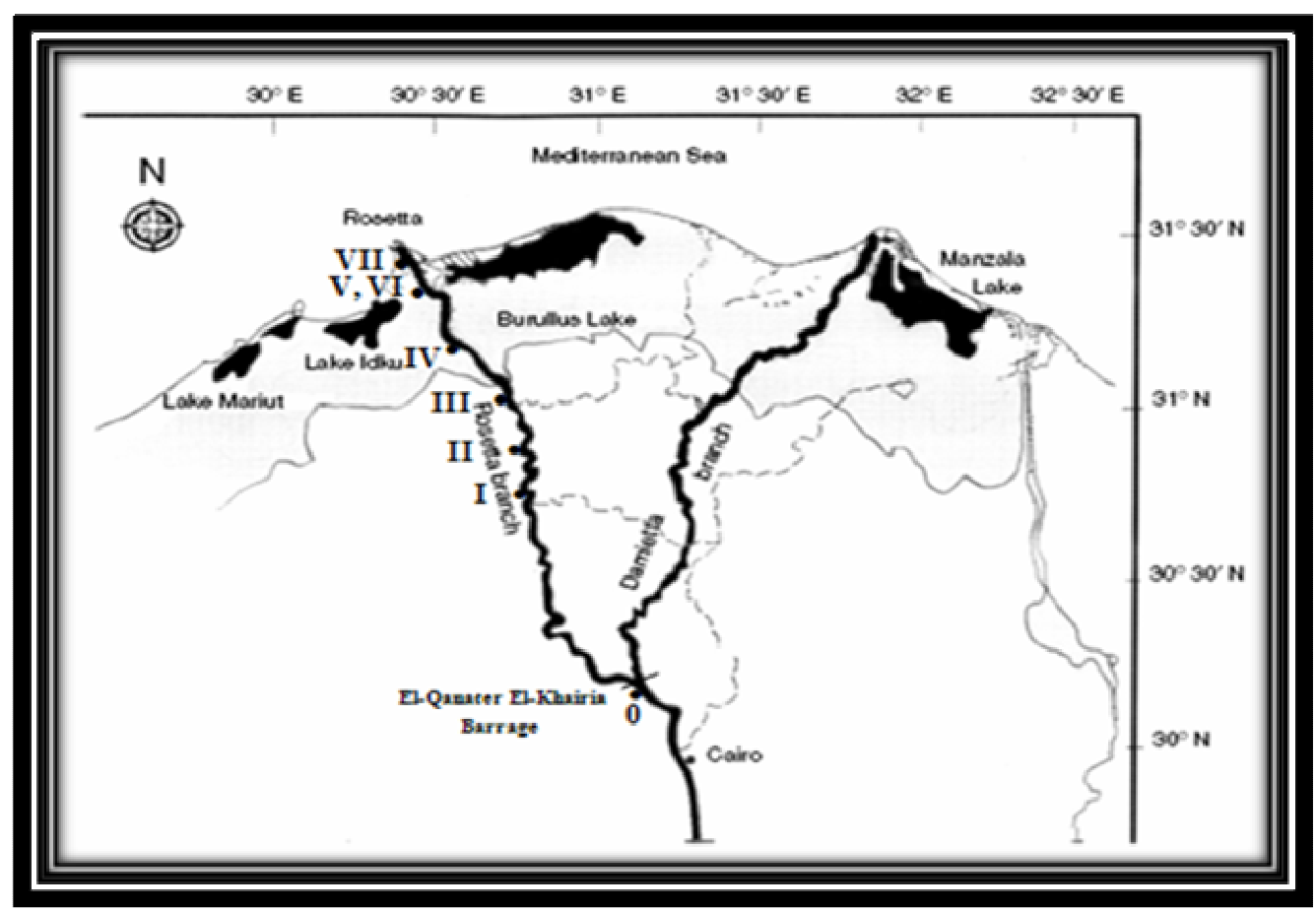

Fig. 1. Study Stations on Rosetta branch of the River Nile (Scale 1:40,00,000).

\section{MATERIALS AND METHODS}

\section{Study area}

The study area extended through El-Gharbia and El-Beheira governorates, from which seven stations were selected to represent Rosetta branch of the river Nile (Map: 1); five stations before Edfina barrage (stations I, II, III, IV and V) and two stations after Edfina barrage (stations VI and VII). The stations were determined by using GPS (model: 315 MAGELLAN). Station (I) was represented in Kafr El-Zayat city (30 $40^{\circ} 55^{\prime \prime} \mathrm{N}$ and $\left.30^{\circ} 48^{\prime} 23^{\prime \prime} \mathrm{E}\right)$, (II) Shabrakhit city ( $31^{\circ} 01^{\prime} 53^{\prime \prime} \mathrm{N}$ and $\left.30^{\circ} 43^{\prime} 13^{\prime \prime} \mathrm{E}\right)$, (III) El-Rahmania city (31 $06^{\circ} 34^{\prime \prime} \mathrm{N}$ and $30^{\circ} 38^{\prime} 59^{\prime \prime}$ E), (IV) El-Mahmoudia city (31 $\left.111^{\prime} 10^{\prime \prime} \mathrm{N}, 30^{\circ} 31^{\prime} 58^{\prime \prime} \mathrm{E}\right),(\mathrm{V})$ before Edfina barrage at Edfina city $\left(31^{\circ} 18^{\prime} 20^{\prime \prime} \mathrm{N}\right.$ and $30^{\circ} 31^{\prime} 00^{\prime \prime}$ E), (VI) after Edfina barrage at Edfina city $\left(31^{\circ} 18^{\prime} 23^{\prime \prime} \mathrm{N}\right.$ and $\left.30^{\circ} 31^{\prime} 01^{\prime \prime} \mathrm{E}\right)$, and station (VII) Rashid city ( $31^{\circ} 24^{\prime} 21^{\prime \prime} \mathrm{N}$ and $30^{\circ} 25^{\prime} 36^{\prime \prime}$ E). All area of Rosetta branch after Edfina barrage receives the fresh Nile water through Edfina barrage as well as drainage water flowing from Lake Burollus through Brimbal Canal. Also, The Mediterranean Sea water invaded Rosetta branch after the construction of Edfina barrage.

\section{SAMPLE COLLECTION}

\section{Sampling of algae}

Algal samples were collected from the previous five stations according to Sourina (1981). Collection of samples was performed seasonally for two successive years from August 2006 to April 2008.

\section{Counting of phytoplankton}

Counting of phytoplankton was done following Sourina (1981). After shaking $10 \mathrm{ml}$ concentrated material, an aliquot was withdrawn by a pipette and placed into a Max Levy Counting Chamber Haemocytometer. All the areas were counted and results were expressed as number of individuals of phytoplankton per liter. 
Table 1. Seasonal variations in the highest and lowest total number of individuals of phytoplankton taxa of different algal divisions $\left(x \mathbf{1 0}^{6} \mathrm{~L}^{-1}\right)$ of Rosetta branch of the river Nile. (Cyano.=Cyanophycophyta; Bacill. $=$ Bacillariophycophyta $;$ Xanth. $=$ Xanthophycophyta $;$ Pyrro. $=$ Pyrrophycophyta $;$ Euglen. $=$ Euglenophycophyta and Chloro. $=$ Chlorophycophyta and $S u=$ summer; $W n=$ winter; Sp = spring; At = autumn; 2006 $=/ 06 ; 2007=0 / 7$ and $2008=/ 08$ ).

\begin{tabular}{|c|c|c|c|c|c|c|c|c|c|}
\hline \multirow[t]{3}{*}{ Stations } & \multirow{3}{*}{$\begin{array}{c}\text { Total } \\
\text { number } \\
\text { of algal } \\
\text { taxa }\end{array}$} & \multicolumn{8}{|c|}{$\begin{array}{l}\text { Seasonal variations in the highest and lowest total number of individuals of identified } \\
\text { taxa of different algal divisions }\left(x_{10}^{6} L^{-1}\right)\end{array}$} \\
\hline & & \multirow[t]{2}{*}{ Values } & \multicolumn{7}{|c|}{ Algal divisions } \\
\hline & & & Cyano. & Bacill. & Xanth. & Pyrro. & Euglen. & Chloro. & Total \\
\hline \multirow[t]{2}{*}{ I } & 192 & Highest & $\begin{array}{l}0.9492 \\
(\mathrm{Sp} / 08)\end{array}$ & $\begin{array}{l}3.9087 \\
(\mathrm{At} / 07)\end{array}$ & $\begin{array}{l}0.0599 \\
(\mathrm{Su} / 07)\end{array}$ & $\begin{array}{l}0.1998 \\
(\mathrm{Su} / 06)\end{array}$ & $0.4996(\mathrm{Sp} / 07)$ & $\begin{array}{l}12.532 \\
(\mathrm{Su} / 07)\end{array}$ & $\begin{array}{l}14.8887 \\
(\mathrm{Su} / 07)\end{array}$ \\
\hline & & Lowest & $\begin{array}{l}0.369(\mathrm{At} / \\
07)\end{array}$ & $\begin{array}{l}0.2149 \\
(\mathrm{At} / 06)\end{array}$ & $\begin{array}{c}\text { - ve (At/ } \\
06 \text { and } 07 \\
+\mathrm{Wn} / 06 \\
\text { and } 07+ \\
\mathrm{Sp} / 08)\end{array}$ & $\begin{array}{c}- \text { ve } \\
\text { (Wn and } \\
\text { Sp/07) }\end{array}$ & $\begin{array}{c}0.0099 \\
(\mathrm{Wn} / 08)\end{array}$ & $\begin{array}{c}0.4877 \\
(\mathrm{Wn} / 08)\end{array}$ & $\begin{array}{c}1.2532 \\
(\mathrm{Wn} / 08)\end{array}$ \\
\hline \multirow[t]{2}{*}{ II } & 172 & Highest & $\begin{array}{l}0.5876 \\
(\mathrm{Su} / 07)\end{array}$ & $\begin{array}{l}1.1937 \\
(\mathrm{At} / 07)\end{array}$ & & $\begin{array}{l}0.0748 \\
(\mathrm{At} / 06)\end{array}$ & $\begin{array}{l}0.1635 \\
(\mathrm{Su} / 07)\end{array}$ & $\begin{array}{c}9.8098 \\
(\mathrm{Su} / 07)\end{array}$ & $\begin{array}{l}11.2464 \\
(\mathrm{Su} / 07)\end{array}$ \\
\hline & & Lowest & $\begin{array}{l}0.0496( \\
(\mathrm{Wn} / 8)\end{array}$ & $\begin{array}{c}0.0226 \\
(\mathrm{At} / 06)\end{array}$ & & $\begin{array}{c}-\mathrm{ve} \\
(\mathrm{Wn} / 07)\end{array}$ & $\begin{array}{c}0.0099 \\
(\mathrm{Wn} / 08)\end{array}$ & $\begin{array}{c}0.2479 \\
(\mathrm{Wn} / 08)\end{array}$ & $\begin{array}{c}0.8353 \\
(\mathrm{Wn} / 08)\end{array}$ \\
\hline \multirow[t]{2}{*}{ III } & 155 & Highest & $\begin{array}{c}0.6539 \\
(\mathrm{Su} / 07)\end{array}$ & $\begin{array}{c}1.4529 \\
(\mathrm{At} / 07)\end{array}$ & & $\begin{array}{c}0.3298 \\
(\text { At/ 06) }\end{array}$ & $\begin{array}{c}0.2494 \\
(\mathrm{Wn} / 07)\end{array}$ & $\begin{array}{c}4.8312 \\
(\mathrm{Sp} / 07)\end{array}$ & $\begin{array}{c}5.9709 \\
(\mathrm{Sp} / 07)\end{array}$ \\
\hline & & Lowest & $\begin{array}{c}0.2333 \\
(\mathrm{Wn} / 08)\end{array}$ & $\begin{array}{c}0.0022 \\
(\mathrm{At} / 06)\end{array}$ & & $\begin{array}{c}\text { - ve }(\mathrm{Wn} \\
\text { and } \mathrm{Sp} / 07)\end{array}$ & $\begin{array}{c}0.0198 \\
(\mathrm{Wn} / 08)\end{array}$ & $\begin{array}{c}0.288 \\
(\mathrm{Wn} / 08)\end{array}$ & $\begin{array}{c}0.7838 \\
(\mathrm{Wn} / 08)\end{array}$ \\
\hline \multirow[t]{2}{*}{ IV } & 155 & Highest & $\begin{array}{l}0.4618 \\
(\mathrm{Su} / 06)\end{array}$ & $\begin{array}{l}0.6069 \\
(\mathrm{At} / 07)\end{array}$ & & $\begin{array}{c}0.075 \\
(\mathrm{Su} / 06)\end{array}$ & $\begin{array}{c}0.1499 \\
(\mathrm{Su} / 06)\end{array}$ & $\begin{array}{c}6.6842 \\
(\mathrm{Su} / 07)\end{array}$ & $\begin{array}{c}7.5011 \\
(\mathrm{Su} / 07)\end{array}$ \\
\hline & & Lowest & $\begin{array}{c}0.0496 \\
\text { (At/ 06) }\end{array}$ & $\begin{array}{c}0.0009 \\
(\mathrm{At} / 06)\end{array}$ & & $\begin{array}{c}0.0083 \\
(\mathrm{Wn} / 07)\end{array}$ & $\begin{array}{c}-\mathrm{ve} \\
(\mathrm{Wn} / 08)\end{array}$ & $\begin{array}{c}0.2882 \\
(\mathrm{Wn} / 08)\end{array}$ & $\begin{array}{c}0.4274 \\
(\mathrm{At} / 06)\end{array}$ \\
\hline \multirow[t]{2}{*}{ V } & 122 & Highest & $\begin{array}{l}0.3097 \\
(\mathrm{Su} / 07)\end{array}$ & $\begin{array}{c}1.4189 \\
(\mathrm{sp} / 07)\end{array}$ & & $\begin{array}{c}0.0899 \\
(\mathrm{Sp} / 08)\end{array}$ & $\begin{array}{c}0.0875 \\
(\mathrm{Su} / 07)\end{array}$ & $\begin{array}{c}6.5425 \\
(\mathrm{Su} / 07)\end{array}$ & $\begin{array}{c}7.4864 \\
(\mathrm{Su} / 07)\end{array}$ \\
\hline & & Lowest & $\begin{array}{c}0.0297 \\
(\mathrm{Wn} / 08)\end{array}$ & $\begin{array}{l}0.0023 \\
(\mathrm{At} / 06)\end{array}$ & & $\begin{array}{c}-\mathrm{ve} \\
(\mathrm{Wn} / 07)\end{array}$ & $\begin{array}{c}-\mathrm{ve} \\
(\mathrm{Wn} \text { and } \mathrm{Sp} / \\
08)\end{array}$ & $\begin{array}{c}0.1787 \\
(\mathrm{Wn} / 08)\end{array}$ & $\begin{array}{c}0.403 \\
(\mathrm{Su} / 06)\end{array}$ \\
\hline \multirow[t]{2}{*}{ VI } & 116 & Highest & $\begin{array}{c}0.2399 \\
(\mathrm{At} / 07)\end{array}$ & $\begin{array}{l}1.5975 \\
(\mathrm{At} / 07)\end{array}$ & & $\begin{array}{c}1.6217 \\
(\mathrm{Sp} / 07)\end{array}$ & $\begin{array}{c}0.0265 \\
\text { (At/ 07) }\end{array}$ & $\begin{array}{c}2.974(\mathrm{Su} / \\
07)\end{array}$ & $\begin{array}{c}4.2092 \\
(\mathrm{Su} / 07)\end{array}$ \\
\hline & & Lowest & $\begin{array}{c}0.0198 \\
\text { (At/ 06) }\end{array}$ & $\begin{array}{l}0.0122 \\
(\mathrm{Sp} / 08)\end{array}$ & & $\begin{array}{c}- \text { ve } \\
(\mathrm{Wn} / 07)\end{array}$ & $\begin{array}{c}-\mathrm{ve} \\
(\mathrm{Su} / 06+\mathrm{Wn} \\
\text { and } \mathrm{Sp} / 08)\end{array}$ & $\begin{array}{c}0.0843 \\
(\mathrm{Su} / 06)\end{array}$ & $\begin{array}{c}0.2508 \\
(\mathrm{Sp} / 08)\end{array}$ \\
\hline \multirow[t]{2}{*}{ VII } & 108 & Highest & $\begin{array}{c}0.1397 \\
\text { (At/ 07) }\end{array}$ & $\begin{array}{l}0.6456 \\
(\mathrm{At} / 07)\end{array}$ & & $\begin{array}{c}0.211 \\
(\mathrm{Sp} / 07)\end{array}$ & & $\begin{array}{c}1.2079 \\
(\mathrm{Wn} / 07)\end{array}$ & $\begin{array}{l}1.4575 \\
\text { (At/ 07) }\end{array}$ \\
\hline & & Lowest & $\begin{array}{c}-\mathrm{ve} \\
(\mathrm{At} / 06)\end{array}$ & $\begin{array}{l}0.0003 \\
(\mathrm{At} / 06)\end{array}$ & & $\begin{array}{c}-\mathrm{ve} \\
(\mathrm{At} / 06)\end{array}$ & $\begin{array}{c}-\mathrm{ve}(\mathrm{Su} / 06 \text { and } \\
7+\mathrm{At} / 06+ \\
\mathrm{Wn} / 08+\mathrm{Sp} / \\
06 \text { and } 8)\end{array}$ & $\begin{array}{c}0.0099 \\
(\text { At/ 06) }\end{array}$ & $\begin{array}{c}0.0102 \\
(\mathrm{At} / 06)\end{array}$ \\
\hline
\end{tabular}

Extraction of total chlorophyll of was discarded and the residual pellet was phytoplanktonic samples

resuspended in $5 \mathrm{ml}$ of $95 \%$ DMSO, homogenized

Total chlorophyll was extracted by dimethyl sulfoxide (DMSO) according to Burnison (1980) as follows:

Five $\mathrm{ml}$ of the algal suspension was centrifuged at $3500 \mathrm{rpm}$ for $5 \mathrm{~min}$. The supernatant and kept for $5 \mathrm{~min}$ at $70^{\circ} \mathrm{C}$ in water bath. Such extract contains total chlorophyll and cell carotenoids. The extracted cells were recentrifuged again at $3500 \mathrm{rpm}$ for 5 minutes. The extracted solution was measured by reading the absorbance 
(A) of the pigment extract spectrophotometrically (PERKIN-ELMER LAMBDA 2 UV/VIS) at 666 $\mathrm{nm}$. The chlorophyll concentration in the extract was calculated according to Seely et al. (1972).

Total chlorophyll $\left(\mathrm{mg} \mathrm{L}^{-1}\right)=\mathrm{A} \times \mathrm{D}$ x F; where

$\mathrm{A}=$ absorbance at $666 \mathrm{~nm}, \mathrm{~F}=11.3$ (factor),

$\mathrm{D}=$ volume of extract/sample volume

\section{RESULTS AND DISCUSSION}

The maximum qualitative algal taxa of the seven stations was represented by 192, 172, 155, 155,122, 116 and 108 taxa respectively (Table 1). The maximum total quantitative algal taxa were recorded in summer $2007(14,888,700,11,2464$, 7,5011, 7,4864 and 4,2092 individuals $\mathrm{L}^{-1}$ at stations I, II, IV, V and VI respectively); during spring 2007 at station (III: 5,9709) and during autumn 2007 at station (VII: 1,4575).

Quantitative alxal taxa reached its lowest number in winter $2008(1,253,200-835,300$ and 783,800 individuals $\mathrm{L}^{-1}$ at stations I, II and III respectively); in autumn 2006 at station IV (427,400 individuals $\left.\mathrm{L}^{-1}\right)$ and VII $(010,200$ individuals $\mathrm{L}^{-1}$ ); in summer 2006 at station $\mathrm{V}$ (403,000 individuals $\mathrm{L}^{-1}$ ) and during spring 2008 at station VI $\left(250,800\right.$ individuals $\left.\mathrm{L}^{-1}\right)$. Quantitatively, at station (I), Xanthophycophyta, Pyrrophycophyta and Euglenophycophyta, had no role in the algal biomass, while Pyrrophycophyta and Euglenophycophyta had generally low quantitative values in the algal standing crop of stations (II, III, IV, V, VI). Regarding Cyanophycophyta, Pyrrophycophyta and Euglenophycophyta, they had no role in the algal biomass at station VII. According to the total number of individuals, the phytoplankton in Rosetta branch of the River Nile at the most studied stations (I, II, IV, V and VI) had Chlorocharacter in summer 2007.

The results of total chlorophyll contents of the recorded algae of Rosetta branch before and after Edfina barrage during the whole period of study are represented in Table 2, Figs. 2 to 8 . At all stations, the total chlorophyll contents of the identified algae reached their maximum peaks during summer 2007 (23 - 15.63 - 18.33 - 9.66 $20.98-13.34$ and $12.15 \mathrm{mg} \mathrm{L}^{-1}$, respectively) comparing with the total chlorophyll contents in other seasons. The lowest values of total chlorophyll contents of the phytoplankton were detected in autumn 2007 (0.47 - 0.68 and $0.47 \mathrm{mg}$ $\mathrm{L}^{-1}$ at stations I, III and V respectively); in winter 2007 (0.47 and $0.67 \mathrm{mg} \mathrm{L}^{-1}$ at stations II and IV respectively); during spring $2008\left(0.21 \mathrm{mg} \mathrm{L}^{-1}\right)$ at station VI and during autumn $2006\left(0.60 \mathrm{mg} \mathrm{L}^{-1}\right)$ at station VII.

Table 2. Total chlorophyll contents $\left(\mathrm{mg} \mathrm{L}^{-1}\right)$ of phytoplankton of Rosetta branch of the river Nile.

\begin{tabular}{|c|c|c|c|c|c|c|c|c|}
\hline \multirow[t]{3}{*}{ Stations } & \multicolumn{8}{|c|}{ Total chlorophyll contents $\left(\mathrm{mg} \mathrm{L}^{-1}\right)$} \\
\hline & \multicolumn{4}{|c|}{$\begin{array}{c}1^{\text {st }} \text { studied year } \\
\text { (summer } 2006 \text { to spring 2007) }\end{array}$} & \multicolumn{4}{|c|}{$\begin{array}{c}2^{\text {nd }} \text { studied year } \\
\text { (summer2007 to spring 2008) }\end{array}$} \\
\hline & $\mathrm{Su} / \mathrm{o} 6$ & At/06 & $\mathrm{Wn} / 07$ & $\mathrm{Sp} / 07$ & $\mathrm{Su} / 07$ & At/07 & $\mathrm{Wn} / 08$ & $\mathrm{Sp} / 08$ \\
\hline I & 21.40 & 9.96 & 0.70 & 16.20 & 23.0 & 0.47 & 1.56 & 4.98 \\
\hline II & 9.34 & 9.65 & 0.47 & 3.69 & 15.63 & 1.61 & 1.19 & 3.17 \\
\hline III & 5.76 & 1.40 & .09 & 5.40 & 18.33 & 0.68 & 1.19 & 2.18 \\
\hline IV & 0.83 & 1.09 & 0.67 & 4.31 & 9.66 & 0.73 & 1.19 & 2.75 \\
\hline $\mathbf{V}$ & 0.93 & 1.40 & 5.56 & 1.40 & 20.98 & 0.47 & 0.93 & 2.49 \\
\hline VI & 5.05 & 0.72 & 1.81 & 0.67 & 13.34 & 1.87 & 1.71 & 0.21 \\
\hline VII & 2.02 & 0.60 & 5.56 & 0.62 & 12.15 & 1.14 & 1.11 & 1.40 \\
\hline
\end{tabular}




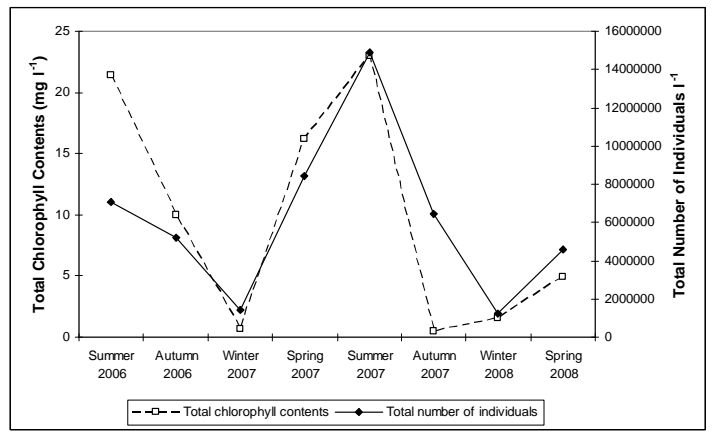

Fig. 2. Relationship between total chlorophyll contents and total number of individuals of Rosetta branch at Kafr El-Zayat city (station I).

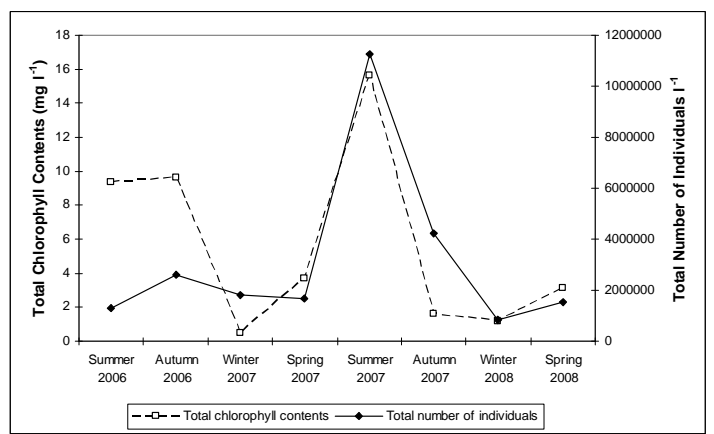

Fig. 3. Relationship between total chlorophyll contents and total number of individuals of Rosetta branch at Shabrakhit city (station II).

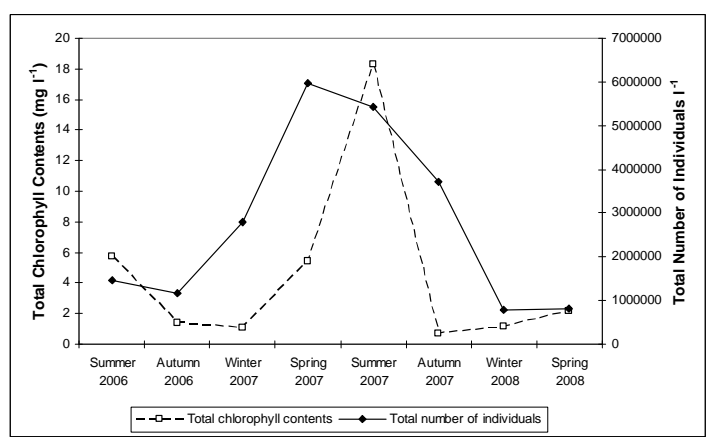

Fig. 4. Relationship between total chlorophyll contents and total number of individuals of Rosetta branch at ElRahmania city (station III).

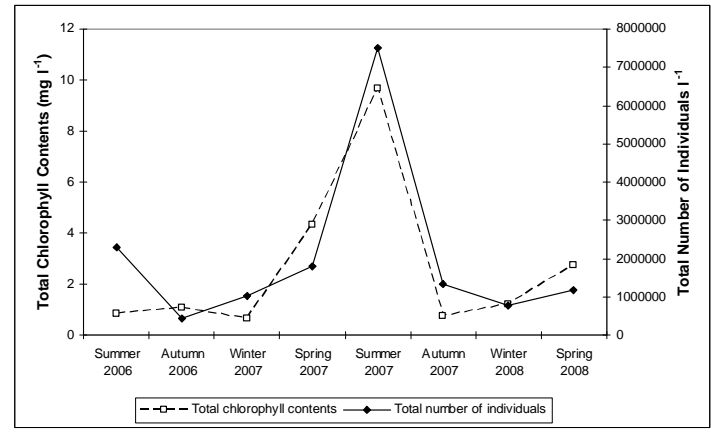

Fig. 5. Relationship between total chlorophyll contents and total number of individuals of Rosetta branch at ElMahmoudia city (station IV).

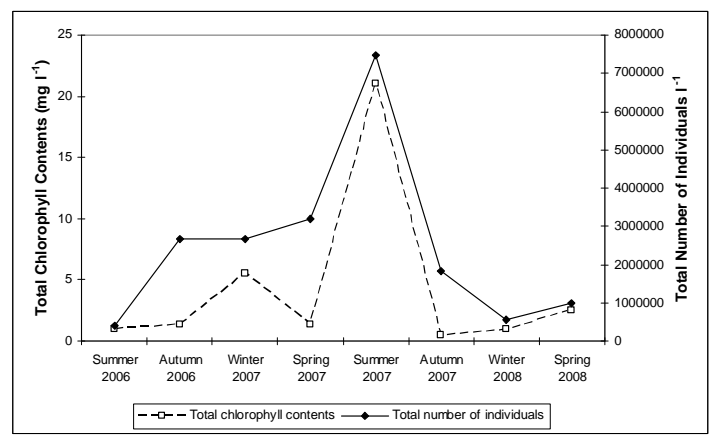

Fig. 6. Relationship between total chlorophyll contents and total number of individuals of Rosetta branch before Edfina barrage at Edfina city (station V).

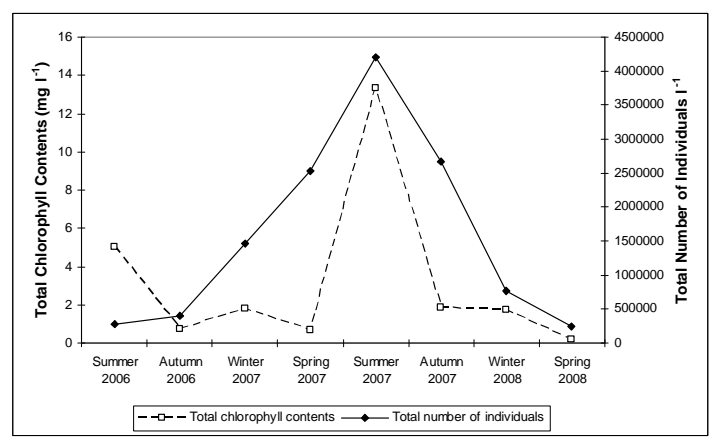

Fig. 7. Relationship between total chlorophyll contents and total number of individuals of Rosetta branch after Edfina barrage at Edfina city (station VI). 


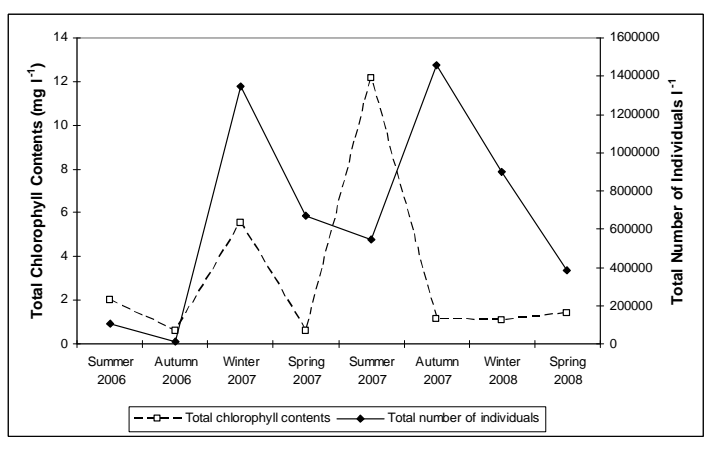

Fig. 8. Relationship between total chlorophyll contents and total number of individuals of Rosetta branch at Rashid city (station VII).

Station I showed the highest maximum peaks in total chlorophyll, maximum quantitative algal individuals and qualitative algal taxa. The present study showed that peak periods of chlorophyll coincided with peak periods of phytoplanktonic number. This is in agreement with the observations of Ekpenyong (2000), Marisol and Jordi (2000), Descy et al. (2005), Todd et al. (2008), Elewa et al. (2009) and Senthil et al. (2009). A similar variation was observed between the fluctuations of total chlorophyll contents of the phytoplankton and those of total number of individuals at all investigated stations of Rosetta branch.

\section{REFERENCES}

Akpan, E.R. 1994. Seasonal Variation in Phytoplankton Biomass in Relation to Physico-Chemical Factors in the Cross River Estuary of South East Nigeria. Ph.D. Thesis. University of Calabar, Nigeria.

Brando, V., A. Dekker, A. Marks, Y. Qin and K. Oubelkheir. 2006. Chlorophyll and suspended sediment assessment in a macrotidal tropical estuary adjacent to the Great Barrier Reef: spatial and temporal assessment using remote sensing. Cooperative Research Centre for Coastal Zone, Estuary and Waterway Management Technical Report 74.
Burnison, B.K. 1980. Modified dimethyl sulfoxide (DMSO) extraction for chlorophyll analysis of phytoplankton. Can. J. Fish. Aquat. Sci. 37:729-733.

Descy, J.P., M.A. Hardy, S. Sténuite, S. Pirlot, B. Leporoq, I. Kimirei, B. Sekadende, S.R. Mwaitega and D. Sinyenza. 2005. Phytoplankton pigments and community composition in Lake Tanganyika. Freshwater Biology 50:668-684.

Desortová, B. 1981. Relationship between chlorophyll $a$ concentration and phytoplankton biomass in several reservoirs in Czechoslovakia. Int. Revue Ges. Hydrobiol. 66:153-169.

Ekpenyong, E. 2000. Algal biomass and pigment diversity in typical tropical fish ponds. Tropical Ecology 41(1):89-94.

Elewa, A.A., M.B. Shehata, L.F. Mohamed, M.H. Badr and G.S. Abdel Aziz. 2009. Water quality characteristics of the river Nile at delta barrage with special reference to Rosetta branch. Global. J. Environ. Research 3(1):1-6.

Fogg, G.E. 1975. Primary Production. Chemical Oceanography. Vol. 2, $2^{\text {nd }}$ edition, Academic Press. New York.

Hakanson, L. 1994. A review of effect-dosesensitivity models for aquatic ecosystems. Internationale Revue der Gesamten. Hydrobiologie 79:621-667.

Halil, B., P. Laurent and M. Anastasios. 2008. Radiation characteristics of Chlamydomonas reinhardtii $\mathrm{CC} 125$ and its truncated chlorophyll antenna transformants tla1, tlaX and tla1-CWD. International Journal of Hydrogen Energy 33:6467-6483.

Kalchev, R.K., M.B. Beshkova, C.S. Boumbarova, R.L. Tsvetkova and D. Sais. 1996. Some allometric and non-allometric relationships

ECOPRINT VOL 18, 2011 
between chlorophyll- $a$ and abundance variables of phytoplankton. Hydrobiologia 341:235-245.

Marisol, F. and C. Jordi. 2000. The relationship between phytoplankton biovolume and chlorophyll in a deep oligotrophic lake: decoupling in their spatial and temporal maxima. Journal of Plankton Research 22(1):91-105.

Passavante, J.Z.O. and F.A.N. Feitosa. 2004. Dinamica da Produtividade Fitoplanctonica na Zona Costeira Marinha. In: Eskinazi-Leca, E.; Neumann-Leitao, S.; Costa, M.F. (Org.). Oceanografi a - Um. cenUrio tropical. Recife, UFPE, pp. 353-373.

Santos, D.H., M.D.G. Silva-Cunha, M.F. Santiago and J.Z. Passavante. 2010. Characterization of phytoplankton biodiversity in tropical shipwrecks off the coast of Pernambuco, Brazil. Acta Bot. Bras. 24(4):924-934.

Seely, G.R., M.J. Duncan and W.E. Widaver. 1972. Preparative and analytical extraction of pigments from brown algae with dimethyl sulfoxide. Mar. Biol. 12:184-188.

Senthil, C., R. Balasubramanian, B. Ashish and C.D. Keshav. 2009. Biomass production potential of a wastewater alga Chlorella vulgaris ARC 1 under Elevated Levels of $\mathrm{CO} 2$ and Temperature. International Journal Molecular Science 10:518-532.

Shehata, S.A., G.H. Ali and S.Z. Wahba. 2008. Distribution pattern of Nile water algae with reference to its treatability in drinking water. $J$. App. Sci. Res. 4(6):722-730.

Sobhy, E.H.M. 2008. Phytoplankton of River Nile. In: Final Report of Biodiversity of River Nile Project. (ed.) Abd El-Karim, M.S. National Institute of Oceanography and Fisheries, Alexandria and Cairo (in Arabic).

Sourina, A. 1981. Phytoplankton Manual. Pub. Unit. Nat. Educ. Sci. and Cult. Organ. Paris. UNESCO, 334 pp.

Todd, V.R., B.D. Mark, E.G. Lowell, A.M. Corey, M.S. Karen, H. Thomas and R.W. Matt. 2008. Chlorophyll-a as a criterion for establishing nutrient standards in the streams and rivers of Illinois. Journal of Environmental Quality 37:437-447.

Tolstoy, A. 1979. Chlorophyll-a in relation to phytoplankton volume in some Swedish lakes. Arch. Hydrobiol. 85:133-151.

Vörös, L. and J. Padisak. 1991. Phytoplankton biomass and chlorophyll-a in some shallow lakes in central Europe. Hydrobiologia 215:111-119. 